method of preventing the spread of infection is the prompt slaughter of affected animals and those in immediate contact". The work of the Research Committee is costing, he said, $£ 16,000-£ 17,000$ a year. In a written reply to a question, Mr. Morrison stated that the Government has paid out $£ 4,900,233$ in compensation for animals slaughtered on account of foot-and-mouth disease during the twenty years 1917-36. The Royal Society for the Protection of Birds has issued a circular letter asking if there is any evidence that starlings and other birds are responsible for bringing infection into England. The Research Committee, in its report referred to above, does not apparently favour the view that birds are responsible, but nevertheless Mr. Morrison declared that in the opinion of the Ministry, "the present outbreak is caused by migrant birds"

\section{Monument to Wireless Pioneers}

A granite column has been erected by the Marconi Company at Poldhu Cove, Cornwall, on November 21, to mark the site of the former Poldhu wireless station. A plaque on the monument states that the Poldhu wireless station, designed by J. A. (now Sir Ambrose) Fleming, occupied that site from 1900 until 1933. A second plaque states that the Poldhu station was used for the first trans-oceanic service of wireless telegraphy, which was opened with a second Marconi station at Glace Bay, in Canada, in 1902. There is also a third plaque, which commemorates the fact that in 1923 and 1924 C. S. Franklin, inventor of the Franklin beam aerial, directed from there his shortwave wireless beam transmission to Marconi on his yacht Elettra, cruising in the South Atlantic. These experiments laid the foundation of modern high-speed radio-telegraphic communication to and from all quarters of the globe. Mr. H. A. White, chairman of the Marconi Company, who presided, said that Marconi had always realized that inventors working under the auspices of the company which bore his name do not usually receive adequate recognition. Most of the success of modern methods of radiotelegraphy and radiotelephony, and many other wonderful achievements in scientific technique, can be traced back to Sir Ambrose Fleming's invention of the thermionic valve in 1904 .

\section{The German Autobahnen}

CoNSIDERABLE attention has been given recently by scientific and technical workers to the remarkable system of new motorways now in course of construction by the German Government, at the invitation of which a delegation from Great Britain recently made a tour of inspection of the roads, both those in course of construction and also those now completed. of the latter, 650 miles were opened to traffic on September 27, 1936, and it is stated that another 650 miles will be completed each year until a total of some 4,500 miles of new roads are constructed. Only mechanically propelled vehicles are permitted to use the Autobahnen, and the requisite land is purchased by the German Government, proprietors refusing to sell being expropriated, an exchange process between adjacent plots being arranged in such cases. The work gives employment to about 250,000 workers, and is financed directly by the Reich. Dual concrete carriageways, clover-leaf intersections, and transition curves suited to high-speed traffic are adopted, through and local traffic are segregated, and the mixing, placing, consolidation and finishing of the concrete surfaces is done by mechanical means throughout.

IT is understood that the delegation which visited these roads, composed of representatives of the Automobile Association, the Royal Automobile Club, and the British Road Federation, together with various technical experts, has been asked by the Minister of Transport to present to him its considered views on the German Autobahnen; and at the meeting of the Public Works Congress in London last week, a private session of the delegates was held at which the best method of preparing such a report was discussed. It is clear that although all who have seen these new roads have been greatly impressed by them as an engineering achievement, there is by no means unanimity of opinion in technical circles as to their applicability to conditions in Great Britain. Questions as to land values, possible effect on railway interests, the smaller size of Great Britain as compared with Germany, distribution of industry, and the strategical aspect, make the matter a difficult problem. It is suspected that methods easy of adoption in a totalitarian State may prove to be an entirely different proposition in Great Britain.

\section{Richard Watson and the Constitution of Elements}

Prof. H. A. Harris, of the Anatomy School, Cambridge, has directed our attention to a statement by Richard Watson (1737-1816), bishop of Llandaff and professor of chemistry at Cambridge, an account of whose work was recently given by Prof. J. R. Partington (Chemistry and Industry, 56, 819; 1937). Prof. Harris quotes from Watson's "Chemical Essays" (vol. 4, Essay 7), "Of the Transmutability of Water into Earth", in which he says "the diversities of bodies subsisting in the universe, will no longer be attributed to the different combinations of earth, air, fire and water, as distinct, undecompounded, immutable principles; but to the different magnitudes, figures, and arrangements of particles of matter of the same kind". This idea of a composition of particles of what were then believed to be elements from simpler particles in different arrangements and motions is to be found also in the "Sceptical Chymist" of Robert Boyle, written in 1661, in which he says : "The greatest part of the affections of matter, and consequently of the Phaenomena of nature, seems to depend upon the motion and the contrivance of the small parts of Bodies", and that "the difference of Bodies may depend meerly upon that of the schemes whereinto their common matter is put . . . so that according as the small parts of matter recede from each other, or work upon each other . . . a Body of this or that denomination is produced". In these statements of Boyle and Watson an idea of the present view of the structure of the elements is expressed. 